J. Perinat. Med. 2 (1974) 101

\title{
Uterine blood flow, oxygen uptake, and vascular resistance of pregnant sheep near term
}

\author{
Wolfgang Künzel, Friedrich Karl Klöck, Heinz-Dieter Junge, Walde- \\ mar Moll
}

Frauenklinik der Medizinischen Hochschule Hannover,

Frauenklinik der RWTH Aachen,

Lehrstuhl II für Physiologie der Universität Regensburg

Received August 6, 1973. Accepted December 10, 1973.

Reduced uterine blood flow may be caused by a reduced arterial blood pressure and by an increased uterine vascular resistance $[2,3,4]$. In addition, reduced uterine blood flow seems to occur normally during vigorous uterine contraction in the expulsive stage of labor [1].

In pregnant rhesus monkeys and in pregnant guinea pigs uterine $\mathrm{O}_{2}$-uptake decreases when uterine blood flow falls below about $80 \mathrm{ml}$ $\min ^{-1} \mathbf{k g}^{-1}[5,7]$.

We were interested to know whether similar relations between uterine $\mathrm{O}_{2}$-uptake and uterine blood flow occur in sheep, the fetal weight of which is similar to that in human. As the available data do not allow to draw conclusions on this relation we measured uterine $\mathrm{O}_{2}$-uptake, uterine blood flow, and uterine vascular resistance in the sheep. The data should give further indications on the effect of reduced uterine blood flow on the fetus.

\section{Methods}

\subsection{Material}

11 Merino-sheep near term were used. The maternal weight was $66.6 \mathrm{~kg}(\mathrm{SD}=7.3 \mathrm{~kg})$. The weight of the uterus was $10.3 \mathrm{~kg}(\mathrm{SD}=5.0 \mathrm{~kg}$ ). The mean fetal weight was $4.4 \mathrm{~kg}(\mathrm{SD}=1.6 \mathrm{~kg})$ and 6 sheep had one and 5 sheep had two fetuses.

\subsection{Anesthesia}

The sheep were anesthetized with pentobarbital (initial dose $20 \mathrm{mg} / \mathrm{kg}$ i. v.; additional infusion at a rate of $5 \mathrm{mg} / \mathrm{kg} / \mathrm{h}$ ).

\section{Curriculum vitae}

Wolfgang KüNZEL, $M$. D., Lecturer at Mediziniscbe Hocbscbule Hannover (Medical Universitj), is at present the chief of the Department of Obstetrics and Perinatology.

He was born in Jull', 1936 in Zwickau, Gerniany. Medical studies in Marburg and Kiel from 1954 to 1960. He was Assistent at the Universitätsfraulenklinik in Kiel until 1968 and at the Institute of Pbysiology' in Hannover until 1970. Since 1970 be is at the Frauenklinik of the Mediqinische Hocbschule in Hannover.

Dissertation entitled: Uterine blood flow, uterine $\mathrm{O}_{2}$-uptake and uterine resistance. Chief areas of interest: Fetal and neonatal physiology; in particular, gas exchange between mother and fetus.

\subsection{Surgical manipulations}

The animals were tracheotomized and ventilated by a Starling pump. For relaxation Alloferin was given. An electromagnetic cuff flowmeter with an inner diameter of $5 \mathrm{~mm}$ was put around the uterine artery. In order to prevent spasms the wall of the uterine artery and the surrounding tissue were infiltrated with a local anesthetic (Scandicain). In spite of this manoeuvre local constriction did occur. Therefore in some sheep uterine blood flow was reduced even at the beginning of the experiment. However we did not intend to present normal values of blood flow and oxygen consumption but the relation between these two parameters. 
Tab. I. Uterine blood flow, oxygen uptake (both related to the combined weight of the fetus, myometrium and placenta), the arterial venous oxygen difference across the uterus, the perfusion pressure (arterial-venous blood pressure), and uterine vascular resistance.

\begin{tabular}{|c|c|c|c|c|c|}
\hline \multirow[t]{2}{*}{$\begin{array}{l}\text { No. of sheep / } \\
\text { No. of meas- } \\
\text { urement }\end{array}$} & $\begin{array}{l}\text { Uterine blood } \\
\text { flow }\end{array}$ & $\begin{array}{c}\text { Uterine } \\
\mathrm{O}_{2} \text {-uptake }\end{array}$ & $\begin{array}{l}\text { Arterio-venous } \\
\text { oxygen } \\
\text { difference }\end{array}$ & $\begin{array}{l}\text { Perfusion } \\
\text { pressure }\end{array}$ & $\begin{array}{l}\text { Uterine } \\
\text { vascular } \\
\text { resistance }\end{array}$ \\
\hline & $\mathrm{ml} \cdot \min ^{-1} \cdot \mathrm{kg}^{-1}$ & $\mathrm{ml} \cdot \min ^{-1} \cdot \mathrm{kg}^{-1}$ & $\mathrm{ml} / 100 \mathrm{ml}$ & $\mathrm{mmHg}$ & $10^{4} \cdot \mathrm{dyn} \cdot \mathrm{s} \cdot \mathrm{cm}^{-5} \mathrm{~kg}^{-1}$ \\
\hline 5.1 & 59 & 3.2 & 5.4 & 55 & 7.45 \\
\hline 5.2 & 97 & 4.2 & 4.3 & 89 & $7.34^{j}$ \\
\hline 9.1 & 91 & 4.7 & 4.2 & 123 & 10.81 \\
\hline 10.1 & 36 & 1.8 & 5.0 & 51 & 11.33 \\
\hline 10.2 & 151 & 8.0 & 5.3 & 104 & 5.51 \\
\hline 11.1 & 108 & 7.2 & 6.7 & 90 & 6.66 \\
\hline 12.1 & 139 & 6.5 & 4.7 & 97 & 5.58 \\
\hline 12.2 & 124 & 4.8 & 3.9 & 100 & 6.45 \\
\hline 13.1 & 65 & 5.2 & 7.9 & 101 & 12.43 \\
\hline 13.2 & 92 & 6.1 & 6.7 & 111 & 9.65 \\
\hline 13.3 & 137 & 6.1 & 4.4 & 119 & 6.95 \\
\hline 14.1 & 62 & 2.5 & 4.0 & 111 & 14.31 \\
\hline 14.2 & 91 & 2.9 & 3.2 & 113 & 9.93 \\
\hline 14.3 & 103 & 5.0 & 4.8 & 105 & 8.15 \\
\hline 15.1 & 28 & 1.9 & 6.8 & 97 & 27.71 \\
\hline 15.2 & 55 & 3.0 & 5.5 & 110 & 16.00 \\
\hline 15.3 & 83 & 3.7 & 4.5 & 102 & 9.83 \\
\hline 15.4 & 85 & 4.0 & 4.7 & 105 & 9.88 \\
\hline 16.1 & 142 & 4.0 & 2.8 & 91 & 5.13 \\
\hline 16.2 & 204 & 5.9 & 2.9 & 91 & 3.57 \\
\hline 17.1 & 51 & 3.4 & 6.6 & 105 & 16.47 \\
\hline 17.2 & 82 & 4.7 & 5.8 & 106 & 10.34 \\
\hline 20.1 & 50 & 2.6 & 5.2 & 97 & 15.52 \\
\hline 20.2 & 109 & 3.8 & 3.5 & 96 & 7.05 \\
\hline
\end{tabular}

\subsection{Measurements and calculations}

The blood pressure in the cannulated vessels was continuously monitored with strain gauge transducers. The $\mathrm{O}_{2}$-concentration of the blood samples were determined with the manometric apparatus of VAN SLYKE.

The oxygen uptake of the uterus was calculated from the uterine blood flow and the $\mathrm{O}_{2}$-concentration difference between the arterial blood and the uterine venous blood. This procedure is based on the assumption that the blood drawn from the main uterine vein is representative for the uterine venous blood. This assumption is not necessarily true and may result in some errors in determining uterine $\mathrm{O}_{2}$-uptake.

Uterine blood flow was measured with an electromagnetic flowmeter, placed around a single uterine artery. If both uterine horns were pregnant, the measured value was related to the weight of the horn where the flowmeter was placed. X-ray photographs after injections of opaque medium into the uterine vessels have shown that the uterine arteries supply only the horn on the respective side in twin pregnancies [6]. When only one horn was pregnant (sheep Nos. 11, 12, 14, 17, and 20) the flowmeter was placed successively around the left and the right uterine artery, and the blood flow ratio of both uterine arteries was determined. During the main part of the experiment the blood flow in only one uterine artery was continuously recorded. The fetal uterine blood flow was calculated from this record, assuming a constant flow ratio of both uterine arteries.

\section{Results}

The data of uterine blood flow, $\mathrm{O}_{2}$-uptake, arterialvenous $\mathrm{O}_{2}$-concentration difference $\left(\mathrm{AVDO}{ }_{2}\right)$, and vascular resistance are listed in Tab. $I$. 
In Fig. 1 uterine $\mathrm{O}_{2}$-uptake of pregnant sheep is related to uterine blood flow. When the uterine blood flow was $140 \mathrm{ml} \mathrm{min-1} \mathrm{kg}^{-1}$ or more the uterine $\mathrm{O}_{2}$-uptake was about $6 \mathrm{ml} \mathrm{min}^{-1} \mathrm{~kg}^{-1}$. When the uterine blood flow was decreased below $100 \mathrm{ml} \mathrm{min}^{-1} \mathrm{~kg}^{-1}$, uterine $\mathrm{O}_{2}$-uptake was reduced to a nearly proportionate extent. In Fig. 2 the $\mathrm{AVDO}_{2}$ across the uterus is related to the uterine blood flow. The $\mathrm{AVDO}_{2}$ was about $4.5 \mathrm{ml} / 100 \mathrm{ml}$ when the uterine blood flow was between 100 and $150 \mathrm{ml} \mathrm{min}^{-1} \mathrm{~kg}^{-1}$.

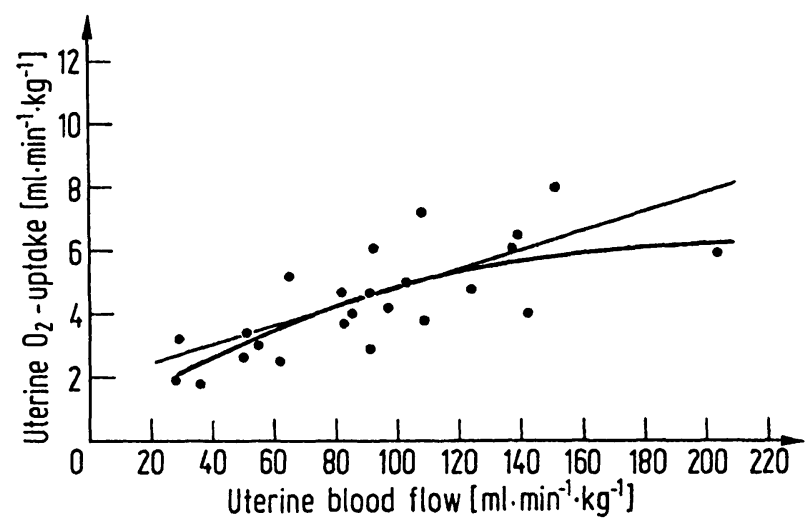

Fig. 1. Uterine $\mathrm{O}_{2}$-uptake related to uterine blood flow in the pregnant sheep near term. The linear regression line shows that uterine $\mathrm{O}_{2}$-uptake was significantly decreased when the uterine blood flow was reduced (VUT, $0_{2}=$ $1.8+0.03$. QuT $)(2 x<0.001)$. The parabolic regression line shows the best approximation to the measured values, but there is no significant difference between these two.

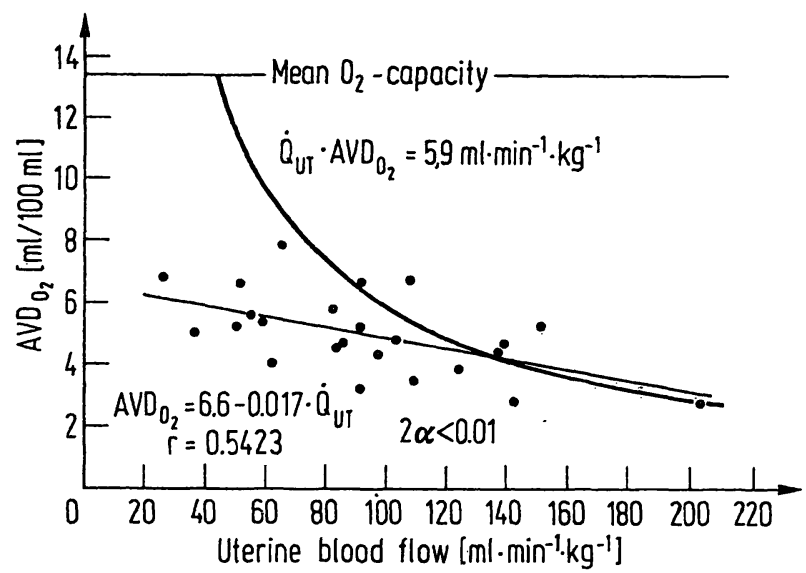

Fig. 2. $\mathrm{AVDO}_{2}$ across the uterus related to uterine blood flow. The thin full line is the linear regression line adapted to the data (points). The thick full curve shows a theoretical line for the $\mathrm{AVDO}_{2}$ we would expect when the uterine $\mathrm{O}_{2}$-uptake remains $5.9 \mathrm{ml} \mathrm{min} \mathrm{mg}^{-1} \mathrm{~kg}^{-1}$. The regression line and the theoretical line deviate from each other when the uterine blood flow is below $100 \mathrm{ml} \mathrm{min}^{-1} \mathrm{~kg}^{-1}$.
There was an inverse linear relationship between the $\mathrm{AVDO}_{2}$ and the uterine blood flow. The thick line in Fig. 2 indicates the theoretical line for the $\mathrm{AVDO}_{2}$ we would expect with a constant uterine $\mathrm{O}_{2}$-uptake of $5.9 \mathrm{ml} \mathrm{min}-1 \mathrm{~kg}^{-1}$. This theoretical line seems to fit the experimental data when the uterine blood flow is above $100 \mathrm{ml}$ $\min ^{-1} \mathrm{~kg}^{-1}$. However, the data at flow rates between $80-100 \mathrm{ml} \mathrm{min}^{-1} \mathrm{~kg}^{-1}$ differ significantly from the line. The same is true for the values at even lower flow rates. In other words: at flow

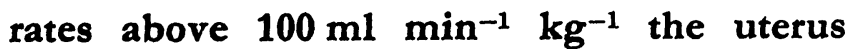
seems to extract the amount of $\mathrm{O}_{2}$ from the maternal blood needed for a constant rate of $\mathrm{O}_{2}$-uptake, whereas at lower flow rates the extraction becomes less; i. e. the $\mathrm{O}_{2}$-uptake drops.

In Fig. 3 uterine $\mathrm{O}_{2}$-uptake is related to uterine vascular resistance. The uterine $\mathrm{O}_{2}$-uptake was

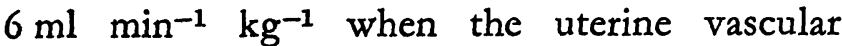
resistance was $2 \cdot 10^{4}$ dyn $\mathrm{s} \mathrm{cm}^{-5} \mathrm{~kg}$. The $\mathbf{O}_{2}$ uptake was reduced by $50 \%$ when the vascular resistance increased threefold. The curve reflects the fact that those changes of uterine blood flow, that are due to changes of uterine vascular resistance, play an important role in reducing uterine $\mathrm{O}_{2}$-uptake.

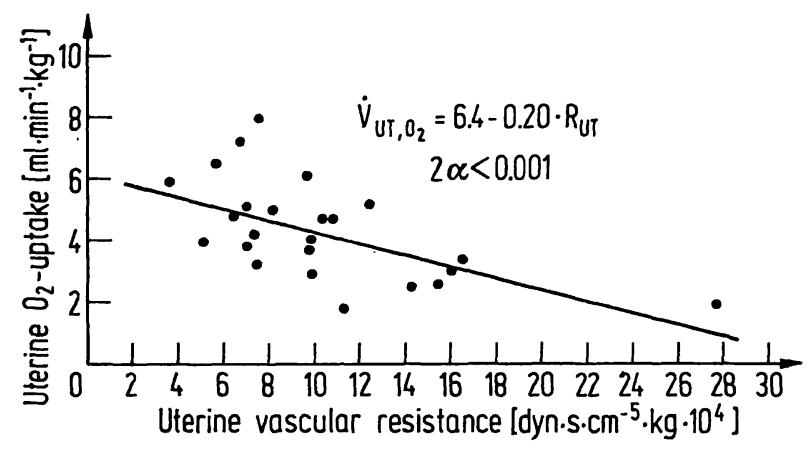

Fig. 3. Uterine $\mathrm{O}_{2}$-uptake related to uterine vascular resistance.

\section{Discussion}

The present results indicate that in the sheep the uterine $\mathrm{O}_{2}$-uptake is reduced when the uterine blood flow falls below $80-100 \mathrm{ml} \mathrm{min}^{-1} \mathrm{~kg}^{-1}$. This finding is similar to that obtained in the rhesus monkey by PARER et al. [7] and in the guinea pigs by KüNZEL and Moll [5]. 


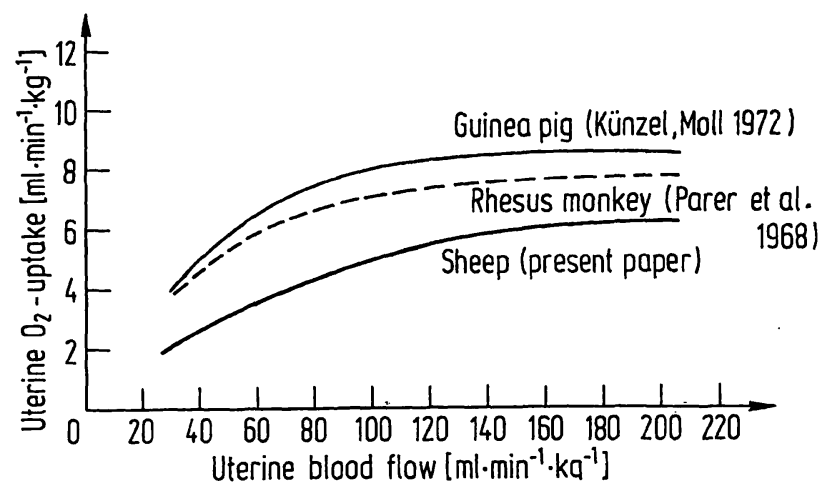

Fig. 4. Uterine $\mathrm{O}_{2}$-uptake related to uterine blood flow in the guinea pig [5], the rhesus monkey [7], and in sheep (present paper). Parabolic regression lines are shown which were adapted to the respective data.

Fig. 4 shows the regression lines which are calculated for the data obtained in the three species mentioned above. For the sake of comparison the respective parabolic regression lines are drawn, even if only in the guinea pigs the sum of squares around the regression line was significantly reduced by replacing the linear lines by parabolic lines. It can be seen that in all three species uterine $\mathrm{O}_{2}$-uptake is reduced when uterine blood flow falls below $80-100 \mathrm{ml} \mathrm{min}^{-1} \mathrm{~kg}^{-1}$. In the view of this similarity between species differing in fetal weight as well as in placental structure it seems likely that a similar relation between uterine $\mathrm{O}_{2}$-uptake and uterine blood flow occurs also in man.

Fig. 4 allows to compare uterine $\mathrm{O}_{2}$-uptake of the three species at the same uterine blood flow per uterine weight (weight of the uterine muscle and its content, i. e. the placenta, and the fetus). The uterine $\mathrm{O}_{2}$-consumption seems to be inversely related to the fetal weight. The sheep have the highest fetal weight and the lowest $\mathrm{O}_{2}$-consumption per weight. On the other hand, the guinea pig and the rhesus monkey have the lowest fetal weight and the highest $\mathrm{O}_{2}$-consumption $(2 \mathrm{P}<0.02)$. Thus we find in the fetus a similar relation between body weight and oxygen consumption per weight as in the adult.

\section{Summary}

\section{Materials and Methods}

11 pregnant sheep near term (fetal weight $4.4 \mathrm{~kg}, \mathrm{SD}=$ $1.6 \mathrm{~kg}$ ) were aneșthetized with pentobarbital. Electromagnetic cuff flow meters were put around one uterine artery and the blood flow was measured. The brachial artery and the uterine vein were cannulated. The blood pressure was measured in these vessels. Blood samples were drawn, the oxygen concentrations were measured in the manometric apparatus of VAN SLYKE. From the uterine blood flow and the $\mathrm{AVDO}_{2}$ across the uterus the uterine $\mathrm{O}_{2}$-uptake was calculated.

\section{Results and Conclusions}

Uterine $\mathrm{O}_{2}$-uptake was related to uterine blood flow (Fig. 1). At flow rates above $140 \mathrm{ml} \mathrm{min} \mathbf{~ k g}^{-1}$ uterine

$\mathrm{O}_{2}$-uptake had a value of about $6 \mathrm{ml} \mathrm{min}-1 \mathrm{~kg}^{-1}$. A reduction of uterine blood flow below $100 \mathrm{ml} \mathrm{min} \mathrm{min}^{-1}$ $\mathrm{kg}^{-1}$ resulted in a proportionate fall of uterine $\mathrm{O}_{2}$ uptake.

Uterine $\mathrm{O}_{2}$-uptake was correlated with uterine vascular resistance (Fig. 3). This indicates that flow reduction caused by an increased vascular resistance plays an important role in fetal hypoxia.

Comparing the data obtained in guinea pigs, thesus monkeys and sheep (Fig. 4) we find a similar relation between the uterine $\mathrm{O}_{2}$-uptake and the uterine blood flow. The maximum uterine $\mathrm{O}_{2}$-uptake per weight, however, seems to be inversely related to the fetal weight.

Keywords: Blood flow, fetus, hypoxia, oxygen uptake, uterus, vascular resistance.

\section{Zusammenfassung}

Uterusdurchblutung, Sauerstoffaufnahme und Gefäßwiderstand beim trächtigen Schaf am Ende der Tragzeit.

\section{Untersuchungsgut und Methodik}

11 trächtige Schafe am Ende der Tragzeit (Fetalgewicht 4,4 $\mathrm{kg} \mathrm{SD}=1,6 \mathrm{~kg}$ ) wurden mit Pentobarbital anästhesiert. Um die A. uterina wurde ein elektromagnetisches Cuff-Flow- meter angebracht und die Durchblutung gemessen. Die A. brachialis und die V. uterina wurden kanüliert. In diesen Gefäßen wurde der Blutdruck gemessen. In den Blutproben wurde die Sauerstoffkonzentration manometrisch nach van SLYKE bestimmt. Aus der Durchblutung des Uterus und der $\mathrm{AVDO}_{2}$ am Uterus wurde die uterine Sauerstoffaufnahme berechnet. 


\section{Ergebnisse und Schlußfolgerungen}

Es bestand eine Beziehung zwischen der uterinen $\mathrm{O}_{2}$-Aufnahme und der Uterusdurchblutung (Fig. 1). Bei einer Durchblutung über $140 \mathrm{ml} \mathrm{min} \mathrm{mg}^{-1}$ betrug die

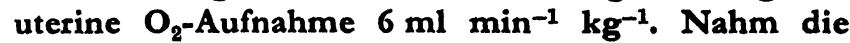
uterine Durchblutung unter $100 \mathrm{ml} \mathrm{min}^{-1} \mathrm{~kg}^{-1} \mathrm{ab}$, so erfolgte auch eine Abnahme der uterinen $\mathrm{O}_{2}$-Aufnahme.

Die uterine $\mathrm{O}_{2}$-Aufnahme war zum uterinen Gefäßwiderstand korreliert (Fig. 3). Diese Beziehung zeigt, daß eine
Reduktion der Durchblutung als Folge eines erhöhten Gefäßwiderstandes eine wichtige Rolle bei der Entstehung einer fetalen Hypoxie spielt.

Vergleicht man die Ergebnisse von Meerschweinchen, Rhesusaffen und Schafen (Fig. 4), so findet sich eine ähnliche Beziehung zwischen uteriner $\mathrm{O}_{2}$-Aufnahme und uteriner Durchblutung.

Das Maximum der uterinen $\mathrm{O}_{2}$-Aufnahme bezogen auf das Gewicht scheint jedoch eine inverse Beziehung zum Fetalgewicht zu haben.

Schlüsselwörter: Durchblutung, Fet, Gefäßwiderstand, Hypoxie, Sauerstoffaufnahme, Uterus.

\section{Résumé}

Irrigation sanguine de l'utérus, absorption d'oxygène et vasorésistance de moutons pleins à terme.

\section{Sujets et méthodique}

11 moutons pleins arrivant à terme (poids foetal $4,4 \mathrm{~kg}$, $\mathrm{SD}=1,6 \mathrm{~kg}$ ) ont été anesthésiés au pentobarbital. On a placé un Cuff-Flowmeter électromagnétique autour de l'A. uterina et mesuré l'irrigation sanguine. Puis on a canulé l'A. brachialis et la V. uterine pour pouvoir mesurer la pression sanguine dans ces vaisseaux. Dans les épreuves de sang, on a déterminé la concentration d'oxygène selon le procédé manométrique de van Slyke. On a calculé l'absorption d'oxygène utérine à partir de l'irrigation sanguine de l'utérus et l'AVDO 2 à l'utérus.

\section{Résultats et conséquences}

On a constaté alors une relation entre l'absorption $\mathrm{O}_{2}$ utérine et l'irrigation sanguine de l'utérus (Fig. 1). Pour une irrigation sanguine supérieure d $140 \mathrm{ml} \cdot \mathrm{min}^{-1}$. $\mathrm{kg}^{-1}$, on a observé une absorption $\mathrm{O}_{2}$ utérine de $6 \mathrm{ml}$. $\min ^{-1} \cdot \mathbf{k g}^{-1}$. Une diminution de l'irrigation sanguine utérine inférieure à $100 \mathrm{ml} \mathrm{min}{ }^{-1} \mathrm{~kg}^{-1}$ entraînait une baisse de l'absorption $\mathrm{O}_{2}$ utérine.

On a également relevé une corrélation entre l'absorption $\mathrm{O}_{2}$ utérine et la vasorésistance utérine (Fig. 3). Cette relation montre qu'une réduction de l'irrigation sanguine consécutive à une vasorésistance élevée joue un rôle important dans la genèse d'une hypoxie foetale.

$\mathrm{Si}$ on compare les résultats obtenus après examens de cochons d'Inde, de singes thésus et de moutons (Fig. 4), on trouve une relation similaire entre l'absorption $\mathrm{O}_{2}$ utérine et l'irrigation sanguine utérine.

Le maximum d'absorption $\mathrm{O}_{2}$ utérine relative au poids semble, cependant, avoir une relation inverse avec le poids foetal.

Mots-clés: Consommation d'oxygène, foetus, hypoxie, irrigation du sang, utérus, vasorésistance.

\section{Bibliography}

[1] Borell, U., J. Fernström, L. Ohlson, N. Wiqvist: Influence of uterine contractions in the utero-placental blood flow at term. Amer. J. Obstet. Gynec. 93 (1965) 44

[2] Greiss, F. C. jr., D. vaN Wilkes: Effects of sympathomimetic drugs and angiotensin on the uterine vascular bed. Obstet. Gynec. 23 (1964) 925

[3] Greiss, F. C. jr.: Pressure-flow relationship in the gravid uterine vascular bed. Amer. J. Obstet. Gynec. 96 (1966) 41

[4] KüNZEL, W.: Der Zusammenhang zwischen Durchblutung und Gefäßwiderstand des Uterus. In: SALING,
E., J. W. Dudenhausen: Perinatale Medizin Band III. 4. Deutscher Kongreß für Perinatale Medizin, Berlin 1971. Thieme, Stuttgart 1972

[5] KüNZEL, W., W. MolL: Uterine $\mathrm{O}_{2}$-consumption and blood flow of the pregnant uterus. Z. Geburtsh. Perinat. 176 (1972) 108

[6] KüNZEL, W., P. RösElER: Unpublished observations, 1971

[7] Parer, J. T., C. W. de Lannoy, A. S. Hoversland, J. Metcalfe: Effect of decreased uterine blood flow on uterine oxygen consumption in pregnant macaques. Amer. J. Obstet. Gynec. 100 (1968) 813

Priv.-Doz. Dr. W. Künzel

Frauenklinik der Med. Hochschule

Hannover

Abt. I Geburtshilfe u. Perinatologie

Podbielskistr. 380

D-3000 Hannover/Germany 